\title{
WiSE CHILDREN AND THE BLIND ASSASSIN: Fictional (AUTO)Biographies
}

\begin{abstract}
In Wise Children and The Blind Assassin, Carter and Atwood portray older women who narrate their (fictional) life-stories with the freedom and confidence of their age. They tell their versions, now free from the fear of the gaze of the audience and men. Through Dora in Wise Children and Iris in The Blind Assassin, Carter and Atwood draw attention to the relevance of (auto)biography for aging women and their need to find their voice and articulate their story, to be heard and to make sense of their lives. Carter and Atwood raise the issue of bodily changes and their effects on the sense of self. Elderly narrators, Dora and Iris, combat the official history that has previously marginalized and/or silenced them and their sisters, Nora and Laura. As narrators, they offer their own versions of truth, often transgressing the boundaries between fact and fantasy, and inviting readers to co-create their story. As I show, Dora and Iris avoid being caught in a single meaning. I suggest that Dora and Iris inscribe their elderly women's bodies and selves into their stories to produce the multilayered texts of their fictional autobiographies.
\end{abstract}

\section{Keywords}

Angela Carter; Margaret Atwood; Wise Children; The Blind Assassin; aging female body; scrapbook self

\section{Left-handed Histories}

Angela Carter and Margaret Atwood present older women who narrate their (fictional) life-stories with the freedom and confidence that comes with their age. They tell their versions, now free from the fear of the gaze of the audience, their fathers, lovers and husbands. Through Dora in Wise Children and Iris in The 
Blind Assassin, Carter and Atwood draw attention to the relevance of (auto)biography for aging women and their need to find their voice and articulate their story, to be heard and to make sense of their lives. In Literature and Feminism, Pam Morris suggests,

[m]any of the consciousness-raising groups of early feminism used femaleauthored texts to combat women's feelings of isolation and inadequacy. Finding their own emotions, circumstances, frustrations and desires shared, named and shaped into literary form gave (and continues to give) many women [...] a sense that their own existence was meaningful. Morris (1993: 60)

Similarly, the elderly narrators, Dora and Iris, challenge the official history that had previously marginalized and/or silenced them and their sisters, Nora and Laura. They are also trickster narrators, offering their own versions of truth, often transgressing the boundaries between fact and fantasy, and inviting the readers to co-create their story. Dora and Iris avoid being caught in a single meaning: they resist reductive definitions of themselves as innocent victims. Dora and Iris refuse fixity of feminine passivity and virtue. The two old women keep narrating their stories to avoid the final truth of every story, death. This paper discusses the importance of autobiography for aging women in finding their voices and making sense of their lives. Firstly, I deal with playful Wise Children, concentrating on the motifs of the twins' illegitimate status and aging bodies transcribed into scrapbook texts. Then, I compare the novel to Atwood's The Blind Assassin, drawing parallels between the two elderly narrators and their sisters as the theme of sisters' sacrifice seems to echo female silence and passive victimhood, against which both old narrators rebel by telling their versions of family histories.

In my reading, Dora and Iris insert their elderly women's bodies and selves as an essential element in the multilayered texts of their fictional autobiographies. Carter and Atwood raise the topic of bodily changes and their effects on the sense of self. The outcomes of Wise Children and The Blind Assassin are different but so are the narrators' ambitions in telling their stories. Nevertheless, both narrators are energised by their constructions as if their continuing narratives have guaranteed their existence in a Scheherazadean sense: they are telling their story, hence they live. To both narrators, their memoirs give a sense of meaning and satisfaction. Moreover, as they have always been marginalized in their lives by the dominant society (for being women and, in Dora's case, for being a dancer and an illegitimate child), their (auto)biographies give them a sense of completeness and unified identity, as they are now able to articulate their repressed and secret memories.

Patricia Waugh comments on this process, observing that "women writers," even fictional writers in the case of Wise Children and The Blind Assassin, I would add,

are beginning $[\ldots]$ to construct an identity out of the recognition that women need to discover, and must fight for, a sense of unified selfhood, a rational, 
coherent, effective identity. [...] women writers have not yet experienced that subjectivity which will give them a sense of personal autonomy, continuous identity, a history and agency in the world. (Waugh 1989: 6)

Waugh's point is particularly relevant to Iris, who has lived her life in oppression, voluntary blindness and denial. Then, her decision to write her life also means a personal rebellion.

Dora and Iris are both trickster narrators. Their memoirs emphasize the trickster's need to transgress the boundaries of official narratives, official histories as well as the conventions of autobiographical models such as memoir, science fiction, documentary report and Künstlerroman. Appropriations of their autobiographical narratives are particularly closely related to the Bildungsroman; they both transcribe their old and aching bodies into multilayered texts of their selves from early childhood. In depicting their lives, which, in Morris's words, "have been erased, ignored, demeaned, mystified and even idealised" (1993: 60), Dora and Iris challenge official histories and write their own, repressed and highly satirical versions.

Aidan Day uses the word "repression" in a discussion of Dora's and Nora's marginalization. He argues that Melchior, the biological father of Dora and Nora, rather, "repressed his connection with and responsibility for Dora and Nora just as imperialism repressed the realities of subjected peoples. Repression is the key word. Melchior's attachment to legitimacy and 'high' culture is part of a dominant, imperial masculine culture's attempt to repress the kind of 'low' culture with which Dora and Nora are associated" (Day 1998: 204). Day thus creates a link between the illegitimate status of Dora and Nora and the marginalized status of the colonized as well as their association with the popular culture of musicals and cabarets.

In the same vein, Anne Hegerfeldt discusses how Carter's novel deconstructs the binary oppositions (legitimate vs. illegitimate, high culture vs. low culture), replacing them with "less exclusive conceptions of family and culture. Allegorically applying them to Britain as a whole, the novel promotes a vision of a non-hierarchical, pluralistic society" (Hegerfeldt 2003: 351). Elaborating on Hegerfeldt's and Day's studies, I extend the metaphor of a "non-hierarchical, pluralistic society" to the understanding of the (aging) body and the self as a multilayered, pluralistic and or palimpsest-like scrapbook self.

I emphasize Dora's illegitimate status to draw attention to her marginalized position. Dora is able to make a self-assertive shift to the position of power and authority as a writer of her (and her sister's) autobiography. The sisters' illegitimate status divides the "socially acceptable from those (or that) rejected" (Hegerfeldt 2003: 351). Dora, an ex-musical and cabaret dancer, is in control of her own past, of the word choice, the tone, as well as of the remembered events. She is able to take responsibility for her own history and her own memories and chooses an optimistic tone to retell "something nice, something nasty" (Wise Children 4). The seventy-five-year-old narrator feels that it is not only her illegitimate 
status, but also her age, which excludes her from history. Even dressed in clothes "sixty years too young," Dora and Nora are ignored, "which pissed us off, but we decided to tolerate the invisibility of old ladies" (Wise Children 199). Their age and gender had transformed them into the invisible despite their loud voices and excessive make up. Hence, Dora's (auto)biography intends to make them heard and visible. Dora insists on writing herself into her family history.

The twins, Dora and Nora, are the illegitimate children of the Shakespearean actor Melchior Hazard, who denies that he is their father. Melchior's twin brother, Peregrine, acts as Dora's and Nora's surrogate father. The twins never knew their biological mother either. They were raised by Grandma Chance, who may or may not be their blood relative. On her seventy-fifth birthday, Dora chronicles over one hundred years of the Hazard and Chance family history, paying attention to the changing fashions and tastes in show business and ignoring most of the official history of two world wars. In "Writing a History of Difference," Jeffrey Roesner discusses the forms of feminist historiography. He asserts that "[e]arlier feminist historians promised the recognition denied women in the record of public events and wars traditionally called 'history.' This emphasis on the recovery of suppressed facts, however, has more recently come under scrutiny by feminists" (Roesner 2002: 103). I add that Dora chooses her own method of recording her past; she notices resemblances and reoccurring events, which makes her memoir circular rather than linear. She writes her memoir from the marginalized position of women and children whom, according to Grandma Chance, the revengeful old men "hated [...] worst of all" (Wise Children 29). The official history of two world wars is treated with irony: "[...] all the men all over the world get together and make a deal: you kill off our boys and we'll kill off yours." (Wise Children 29).

Dora maintains a light and enthusiastic tone to talk about her, sometimes painful and tragic, life. She consciously decides to "[p]ut it another way" (Wise Children 1). In her memoir, her memories correspond to her personality and playful approach to life: "Let other pens dwell on guilt and misery" (Wise Children 163). Furthermore, as Alison Lee suggests, Dora's narrative is an "unofficial history, one that the old men might consider illegitimate, although many things of which these old men might approve are eliminated from, or parodied by, Dora's narrative" (Lee 1997: 114). As a confidence trickster, Dora recognizes the gaps in her stories, some of which she deliberately keeps open, and she comments on her mis-rememberings and tricks. For example, the stories about Peregrine never fit together, "he gave us all his histories, we could choose which ones we wanted - but they kept on changing" (Wise Children 31). As Dora writes in the introductory lines of her chronicle: "[...] you can't trust things to stay the same" (Wise Children 1). Even though Dora's narrative is full of omissions, it is her version of the family history, the one in which she and Nora take centre stage.

In "Writing a History of Difference: Jeanette Winterson's Sexing the Cherry and Angela Carter's Wise Children," Jeffrey Roessner analyses Dora's method of historiography. Roessner asserts that "memoir stands as compelling history" (2002: 115). He continues that Dora does not simply offer testimony but "invites 
readers to ask why Dora and Nora have the experience they do" (2002: 115). Thus, Dora encourages the readers' imagination and creativity to read their own versions of her (auto)biography. Dora (and Nora) seem to invite their audience to keep singing and dancing with them despite their age and old aching bodies.

\section{Antique But Not Quite Catastrophic Bodies}

The aging dancers, Dora and Nora, face the bodily processes of pain and failure in Wise Children. However, the helplessness and degradation of aging is described, in Peach's words, through "the kind of retrospective which primarily seeks to understand people's lives and especially the mistakes that they made" (2009: 174). This comic approach thus creates a humorous protective shelter against pain and mortality. Death is described by the image of flowers popping up on bomb-sites: "[...] as if to say, life goes on, even if you don't" (Wise Children 163). The humorous and carnivalesque mode defeats the tragedy of individual death in the novel through a repetitive continuity of the generations and obsessive recurrence of family history. The novel, however, draws attention to the limitations of the carnival. Carter reminds readers that every carnival has to end, which is illustrated by a scene in which Dora stops the moment of Peregrine's carnivalesque laughter: "'Life is a carnival,' he said. [...] 'The carnival's got to stop, some time, Perry,' I said" (Wise Children 222). It is clear that Wise Children favours the transgression of the carnival to encourage change, whether social (transformation of a traditional patriarchal family) or cultural (transgression of a gap between the so-called "high" and "low" genres).

At the end of the narrative, the Chance sisters contemplate their deaths and they decide that they cannot afford to die for another twenty years because of the little twins. They think of many songs to sing to the babies they adopt: "[...] all the little kids were singing and dancing in the street the day we were born. There was dancing and singing all along Bard Road that day and we'll go on singing and dancing until we drop in our tracks, won't we, kids. What a joy it is to dance and sing!" (Wise Children 231-32). Laughter helps Dora, the narrator, to keep a distance from injustice and pain. She refuses to "play in tragedy" (Wise Children 154). Dora does not want to write "about the war. Suffice to say it was not carnival, not the hostilities. No carnival" (Wise Children 163). Laughter creates a bridge over the tragic tone of aging, deaths, losses and abandonments, which are the motifs of the novel. It is a bridge over the empty spare rooms, the old photographs from youth and the wrinkled faces.

In Wise Children, Dora and Nora experience their bodies in all their states; even in their old age they "can still lift a leg higher than your average dog" (Wise Children 2) and they exhibit their "antique but not quite catastrophic legs with wild abandon" (Wise Children 197). As Julia Simon asserts, the female body as well as female subject "emerges victorious from the long road of de- and reconstruction it has taken in Carter's fiction" (2004: 247). Simon suggests that 
Carter's female protagonists finally joyfully embody themselves: "God bless the Hazard calcium; it's kept osteoporosis at bay" (Wise Children 6). I suggest that from the painted dolls and wooden marionettes in Carter's earlier fiction, such as The Magic Toyshop (1967) and Heroes and Villains (1969), the selves of Carter's protagonists finally inhabit fleshy bodies that they actually enjoy.

I would like to highlight the following passage from the novel that links Dora's and Nora's old and fragile bodies, their colourful selves and writing in the form of scrapbooks. Grandma Chance used to keep a scrapbook of Dora's and Nora's artistic successes, for which they used to tease her:

We felt bad when we saw those scrapbooks, we remembered how we'd teased her, we'd brought home sausage rolls, and crocodile handbags, but she's kept on snipping out the cuttings, pasting them in. Piles of scrapbooks, the cuttings turned by time to the colour of the freckles on the back of an old lady's hands. Her hand. My hand as it is now. When you touch the old newsprint, it turns into brown dust, like the dust of bones. (Wise Children 78)

Fortunately, when Dora is touched, she does not turn into dust. The touch turns her into a young girl again and makes time stand still. Peregrine's and Dora's chandelier-shaking sex in the bedroom over Melchior's birthday party brings a magic illusion: "[w]hile we were doing it, everything seemed possible" (Wise Children 222). In my reading, their desire reverses the deadly gaze and constructs for the loved one a new, young identity again. When Peregrine tells Dora that she has not changed, she writes: "I saw myself reflected in those bracken-coloured eyes of his. I was a lanky girl with a green bow in her mouse-brown hair" (Wise Children 221). The difference between the way Peregrine sees Dora and the objectifying predatory gaze of the male protagonists in Carter's earlier novels is in his respect and love for her.

In contrast to Peregrine, Iris's husband in The Blind Assassin sees Iris and her sister Laura as nothing more than sexual objects and prey. Like Dora Chance, the eighty-five-year-old Iris chronicles the life of two sisters. While the Chance sisters shared Nora's lover, the Chase sisters have shared not only their affection for Alex Thomas, they also both experienced sexual abuse at the hands of Iris's rich husband. The self-sacrifice of the sisters is a reoccurring theme in Wise Children, which is taken to an even further extent in The Blind Assassin. In Wise Children, Nora grotesquely lends Dora her young lover and after exchanging their perfumes to confuse the young man, Dora can lose her virginity. Later, Dora agrees to get married to Genghis, a film producer, so Nora could marry someone else. Dora comments on it: "I did what Nora wanted because I loved her best" (Wise Children 150). Their sacrifices often include carnivalesque elements as the sisters use strategic disguises to ensure the identity exchanges. However, in The Blind Assassin, the story of the sisters' sacrifice is full of passive silence, which seems to enable abusive and aggressive behaviour. 


\section{Sister Sacrifice: Two for the Price of One}

The act of sister sacrifice has more tragic undertones in The Blind Assassin. For example, Iris marries Richard Griffen and thus sacrifices herself to insure her father's and her sister's well-being. But Laura has taken sacrifice as an ideal literally since childhood. She keeps the secret of Richard's rapes from Iris and sacrifices herself to save Alex Thomas's life and her sister's comfort. Laura's secret sacrifices are combined with Richard's lies. The elderly (auto)biographer Iris Chase-Griffen gives voice to the silenced Laura. At the same time, she finds her own voice as well.

Iris is a confidence trickster and illusionist. Her memoir offers several versions of Iris's and Laura's life, all of them incomplete and incongruent with the official stories told by those in power.

In Margaret Atwood and the Female Bildungsroman, Ellen McWilliams discusses the framing narrative of The Blind Assassin as both a "life's retrospective and a confessional" (2009: 116). According to McWilliams, Iris Chase-Griffen is a "highly self-conscious, intrusive and audaciously unreliable narrator" (2009: 116). Several other critics find Iris Chase an unreliable narrator, including Earl Ingersoll. Ingersoll asserts that Iris "is 'feeding her readers a line' with the bait of a revelation to come when they are 'hooked,' or she is spinning the thread of a web in which unwary readers will eventually become trapped" (2003: 548). I add that it is not only Iris who can be identified as a trickster or unreliable narrator in this story. I suggest that there is also Alex Thomas, who keeps narrating the science fiction stories to his lover. His stories function as echoes of Iris's life and thus he can be identified as a messenger. Laura has also a way of sending obscure messages through her coloured photographs. Like Alex, Laura narrates coded stories, which parallel and complete her sister's narrative.

Iris writes a traditional, linear and chronological autobiography; however, at the same time, the novel is an intricate scrapbook of texts: "[c]onstructed like a Russian wooden doll, the novel is a nested series of stories within stories; and like the nested dolls, one story hides another until it is opened to reveal another one surprisingly similar to it" (Stein 2003:135). Iris's narratives never fit together. The readers are deceived into believing they understand the origins of the sisters' tragedy. It is a combination of secrets, silences, and manipulations practiced by Iris's victimizing husband Richard and his sister Winifred, who keep Iris from learning Laura's version of the story. However, in her own version, Iris keeps substituting narratives for narrative as a result of her (voluntary) blindness and forced silence and also because of the intentional tricks she uses to get revenge for herself and her sister. Ellen McWilliams points out that The Blind Assassin can be read as a "scrapbook version of the self" (2009: 116). Iris's scrapbook novel consists of her private memories as well as of public versions of events presented in newspaper clippings; moreover, it is combined with a science fiction narrative echoing Iris's and Laura's traumatic experience of rape and sacrifice. 
Furthermore, like in Wise Children, the scrapbook self and the scrapbook text are imprinted on the fragile and paper-like skin of the old narrator. Scrapbooks are represented here as a specific kind of écriture féminine. In "Eating, Cleaning, and Writing," $\mathrm{Ku}$ discusses female writing, which "shapes subjects that do not simply counter the other but negotiate with it" (2004: 93). Ku argues that Adelia's scrapbooks and cookbook, Laura's coded notebooks, Iris's confessional memoir and also "various inscriptions on the walls of the female washroom disrupt or dispute monolithic logocentrism" (2004: 98) and thus are examples of écriture feminine as theorized in Hélène Cixous's "The Laugh of the Medusa." According to the critic, female writings in The Blind Assassin "serve to form a female community, where the subjects do not simply negatively define/defend/detach their self against/from the symbolic Other but positively facilitate coexistence with this Other through writing" (Ku 2004: 113). Moreover, their inscriptions, codes in notebooks and scrapbooks enable Iris to 'read' the other women's secrets and their writing provides a commentary on the official versions of their lives.

\section{A Battered Wife Writes Back}

Iris Chase finds her bodily image strange to her, as if it did not belong to her. Her old body and its bodily dysfunctions constantly irritate Iris. In the same manner as her decaying body melts in the text, she melts her private memories in the narrative. In "Margaret Atwood's Female Bodies," Madelaine Davies describes this process: "Iris empties her body of all its words, memories, sensations, and secrets [...]. Without the body there is no text, but here it is also true that without the text there is no body" (2006: 68). Davies suggests that there is a very strong link between Iris's body and her history: Iris's "head felt like a sack of pulp and bones ache like history" (Blind Assassin 43). Davies sees Iris's text as a literal emanation from her body (2006: 64). Thus, Iris's text as a product of her body parallels Cixous's resolute statement "Text: my body" (1997: 352). Cixous, in her seminal essay "The Laugh of the Medusa" (1975), suggests that women produce a female form and female texts which expand the linguistic, historical and cultural conventions only when women write from their bodies: "Write your self. Your body must be heard. Only then will the immense resources of the unconscious spring forth" (1997: 350-51). Fiona Tolan also draws attention to the opposition of silence and speech in the novel and Cixous's manifesto: "Cixous's conflation of body and text is realized in Atwood's novel, in which the failure to speak has a direct impact on the body, facilitating not only the physical abuse of Iris but also the sexual abuse of Laura" (Tolan 2010:79). The silent sacrifice the female characters are associated with is shown as a fatal passivity that seems to enable aggressive violence. The sisters" "silent resistance" (Blind Assassin 203) to Iris's husband and to their paedophile teacher, Mr. Erskine, does not prevent abusive behaviour - it seems to encourage it. Only when Iris stops identifying herself as a passive and innocent victim and admits her own culpability and blindness can 
she write her body into her text - "as into the world and into history" (Cixous 1997: 350). Even though Atwood's version of écriture féminine is different from Cixous's essentialism, we can see that Iris Chase literally and loudly articulates her body and her history into the memoir.

Iris's aging body parallels the text. She herself observes: "I suspect myself of having an odour I myself can no longer detect - a stink of a stale flesh and clouded, aging pee" (Blind Assassin 43). Similarly, the wise sister, Dora, says "the house smells of cat, a bit, but more of geriatric chorine - cold cream, face powder, dress preserves, old fags, stale tea" (Wise Children 2). I find it significant that Carter and Atwood let their narrators talk openly and, perhaps, cynically and self-ironically, about the unspoken miseries of old age.

Iris's narrative reveals the painful history of paedophilia, rape and suicide in the Chase family saga. Richard Chase, after he begins to abuse Iris physically, notes that he has not known any woman to "bruise so easily" (Blind Assassin 455). Iris's bruises then present a code, which "blossomed then faded, like invisible ink held to a candle [...] I was sand, I was snow - written on, rewritten, smoothed over" (Blind Assassin 455). This physical experience of abuse is paralleled in the science-fiction tale told within "The Blind Assassin" novella. The male narrator portrays the silent and passive "Peach Women of Aa'A,": "when you hit the women, no blood came out, only juice. When you hit them harder, they dissolved into sweet mushy pulp"(Blind Assassin 435). Iris similarly sees herself lost, rewritten and sucked up by Richard and Winifred. Iris learns that Winifred collaborated with Richard in her abuse. Winifred functions as a villainess in the line of other collaborators in Atwood's work including the Aunts in The Handmaid's Tale and the girl bullies in Lady Oracle and Cat's Eye. Winifred arranges Richard's and Iris's wedding: when she promises to take Iris in hand, Iris feels her own "will seeping out of" her (Blind Assassin 286). Only when she starts writing her body into her memoir can she find herself and her power again.

In Margaret Atwood: Feminism and Fiction, Fiona Tolan comments on the link between the female body and female text, "[b]y depicting the postmodern metaphor of the body as text with literalism, Atwood, like Cixous, manages to unite the anti-essential metaphor with the physical essentialism of the body, embodying the text as much as she textualizes the body" (2007: 267). Moreover, The Blind Assassin's sympathy with Cixous's feminist concept of écriture féminine is underlined by another bodily metaphor, the metaphor she uses in "Two Countries of Writing," the metaphor of double-handedness: "I have been writing for a long time with my right hand and now I am writing with two hands [...] It's not really contradictory; in a way, it's a complement" (Cixous 1990: 191). Similarly, the true author of Laura's novel is revealed at the end of The Blind Assassin. Iris confesses that "Laura was my left hand, and I was hers. We wrote the book together. It's a left-handed book" (Blind Assassin 627). Laura, silenced by Richard's and his sister's deception, serves as the overpowering "writing hand" after her suicide: "sometimes it seems to me that it's only my hand writing, not the rest of me; that my hand has taken on a life of its own, and will keep going on even if severed 
from the rest of me" (Blind Assassin 457). In "A Commemoration of Wounds", J. Brooks Bouson associates the writing hand with "the hand of fate" that passes the unofficial family history to her granddaughter Sabrina (2003: 267). Iris writes the history of her family and it is totally different from Winifred's official version. Winifred is in power and has a legal right to raise Iris's daughter. Moreover, Iris's history is also illegitimate because her daughter's father was Alex, not her husband. In the character of Winifred, Atwood complicates the oppositions between villainous male predators and innocent female victims. Winifred is a wealthy woman who performs the active role of a "pimp" (Blind Assassin 286), taking Iris's power out of her hands. Finally, Iris is able to rebel against her, not only in a passive aggressive way when she leaves her husband and the child behind but also as an active agent and author of her memoir. Iris claims her voice and the control over her writing.

The control, or better said, the lack of control over Iris's narrative, complicates the fact or fiction dilemma. Iris offers two versions of Laura's story, the cult book which is published under Laura's name, as well as another, (true?) version in Iris's memoir, where Iris acknowledges her authorship and her lover, Alex Thomas. Iris declares that Laura is her collaborator and thus blurs the boundary between herself and Laura. I also think that by stressing the image of recording the "bodiless hand" (Blind Assassin 626), she insists on writing "the truth" (Blind Assassin 626) as she writes down "a number of things it wouldn't be allowed to" if it were left to Iris's "better judgement" (Blind Assassin 457). By sacrificing herself for Sabrina when she reveals her illegitimacy, she gives her a new identity.

Old Iris Chase finds her voice to articulate her version of a woman silenced by Richard Griffen and his sister Winifred as well as by the norms of society. Iris retells Laura's story, because Laura was never able to articulate her own version. Instead, Laura was leaving coded messages, the coloured faces of family photographs, cut out passages from the Bible and a list of dates that encode Richard's rapes. In a way that recalls Atwood's early protagonists, she is unable to verbalize her trauma: in Edible Woman, Marianne bakes a symbolic cake; the unnamed protagonist of Surfacing uses symbolic rituals and drawings, as she distrusts language; in Lady Oracle, Joan metaphorically inscribes her fears into Gothic plots but escapes to confront Bluebeard. It is only Atwood's later protagonists who are trying to find their words to expose the violence and "point the finger at Bluebeard" (Stein 2003: 161). Rennie Wilford in Bodily Harm and Offred in The Handmaid's Tale are eager to tell their stories of the innocent witness. However, the protagonists of Cat's Eye, The Robber Bride, Alias Grace and The Blind Assassin are far from innocent recorders - they are manipulative tricksters: Iris uses these skills to expose her husband's and his sister's deception and immorality. As Brooks Bouson observes:

[b]y placing the story of the two sisters against the larger backdrop of Canadian history and describing World War I, the Depression years, and World War II, it provides a kind of fictional documentation of the ways in which 
gender and class expectations shaped and confined women's lives in the first half of the twentieth century (2003: 252).

I think that this time frame also embraces the shifts in cultural idealizations of women: from a blind and blond virginal bride, Iris is transformed into a woman who is able to admit her guilt and denials.

Iris publishes her first novel under Laura's name. By using her sister's name, she achieves three goals. She acknowledges the love affair with Alex Thomas, but saves herself from public blame. Secondly, her husband, when he believes that Laura had been seeing a lover, kills himself. And finally, Iris reveals that Richard was not Sabrina's grandfather after all. The theme of illegitimacy links Wise Children and The Blind Assassin. The fact of Sabrina's mother's illegitimacy can never be learned. Similarly, Laura's aborted baby may be Richard's as well as Alex's. The theme of illegitimacy returns when Iris realizes that Reenie's child might have been her father's: "I wonder if Laura knew about Reenie and Father, if indeed there was anything to know. I wonder if that is among the many things she knew, but never told" (Blind Assassin 476). Wise Children also makes illegitimacy one of its prevalent themes: Nora and Dora are the illegitimate children of Melchior; Imogen and Saskia are the illegitimate children of Peregrine. The theme of illegitimacy corresponds to the unknown and marginalized versions of family history in both novels. I can only agree with Karen F. Stein that by leaving this message to her granddaughter, "Iris hopes to give her the means of reinventing herself, creating a new identity, a new story" (2003: 150). Iris proves to be a trickster, constantly calling facts into doubt and never giving a voice to the other side of the story: her husband, for example.

\section{Visibility and Voice}

Iris seems to be the blind assassin of her husband as well as of Laura because she was blind to Richard's sexual violence. However, she transforms herself from passive blindness to the active subject of her memoir. She recognizes the power of narration and, because she is "the only survivor," claims her memory is true (Blind Assassin 266). Later, she subverts her commitment to reveal the truth: "I know it's wrong," she says, "not because of what I've set down, but because of what I've omitted. What isn't there has a presence, like the absence of light" (Blind Assassin 484). Because of Iris's unreliability, the questions of the truth of her family history remain open. Iris constantly comments on the difficulties of the writing process and her aspiration to tell the truth:

[t]he only way you can write the truth is to assume that what you set down will never be read. Not by any other person, and not even by yourself at some later date. Otherwise you begin excusing yourself. You must see the 
writing as emerging like a long scroll of ink from the index finger of your right hand; you must see your left hand erasing it (Blind Assassin 345).

Obviously, Iris has not only erased but, by embedding genre stories within stories and newspaper clippings, she implies her own version of family history. In "Atwood's Specular Narrative: The Blind Assassin," Hilde Staels suggests that "Atwood's novels have consistently undercut the illusion of retrieving the truth about reality and about the self" (2004: 160). Iris's fictional memoir calls attention to the blurred boundaries between historical fact and fiction. Iris breaks "the snare of silence" (Cixous 1997: 351) surrounding the sexual trauma that she and Laura suffered. As she slowly realizes her own guilt, she moves from "a silenced victim to someone who takes responsibility" (Vickroy 2013: 273). Old and dying Iris wants to be seen as a complex human being, not only a caricature of a "young woman in a satin dress cut on the bias" (Blind Assassin 292) and a battered wife. Iris recognizes the consequences of her oblivion and writes about her guilt and grief: "But some people can't say where it hurts. They can't calm down. They can't ever stop howling" (Blind Assassin 5). However, in her memoir, she achieves Cixous's vision of the writing woman who lets "[h]er flesh speak true" (Cixous 1997: 351). Atwood's Iris reclaims her power and, similarly to Carter's Dora, encourages her reader to feel "free to reinvent yourself at will" (Blind Assassin 627). Both writers thus celebrate the metamorphoses and complexity of human experience.

Sidonie Smith and Julia Watson point out that "women's autobiography" makes "visible formerly invisible subjects" (1998: 5). Carter's and Atwood's narrators present Dora's and Iris's decision to become heard and visible. Although they are turning blind because of their age, they refuse to be blind to injustice and violence.

As I have shown, Carter and Atwood play with the genre of (auto)biography. Even though Carter employs the carnivalesque mode of writing in contrast to Atwood's realistic strategy, they both highlight the instability of fictional (auto) biography as well as truth and history. Moreover, in both novels the elderly narrators insert not only their memories but also their fragile and aching bodies into their scrapbook narratives. Thus, an important link between the text, the self and the body is created.

\section{References}

Atwood, Margaret (2003) The Blind Assassin. London: Virago.

Bouson, J. Brooks (2003) “"A Commemoration of Wounds Endured and Resented': Margaret Atwood's The Blind Assassin as Feminist Memoir." Critique, 44 (3): 251-269. Academic Search Premier. Accessed on April 15, 2011.

Bouson, J. Brooks, Ed. (2010) Margaret Atwood. The Robber Bride, Alias Grace, Oryx and Crake. London and New York: Continuum.

Carter, Angela (1991) Wise Children. London: Penguin. 
Cixous, Hélène (1997) “The Laugh of Medusa.” In: Warhol, Robyn R. and Diane Price Herndl (eds.) Feminisms: An Anthology of Literary Theory and Criticism. New Brunswick: Rutgers University Press, 347-363.

Cixous, Hélène (1990) "Two Countries of Writing: Theater and Poetical Fiction." In: Flower MacCanner, Juliet (ed.) The Other Perspectives in Gender and Culture: Rewriting Women and the Symbolic. New York: Columbia University Press, 191-208.

Davies, Madeleine (2006) “Margaret Atwood's Female Bodies.” In: Howells, Coral Ann (ed.) The Cambridge Companion to Margaret Atwood. Cambridge: Cambridge University Press, 58-71.

Day, Aidan (1998) Angela Carter: The Rational Glass. Manchester: Manchester University Press.

Flower MacCanner, Juliet (1990) The Other Perspectives in Gender and Culture: Rewriting Women and the Symbolic. New York: Columbia University Press.

Hegerfeldt, A. (2003) "The Stars That Spring from Bastardising: Wise Children Go for Shakespeare (Angela Carter, Wise Children)." Anglia-Zeitschrift Fur Englische Philologie 121 (3): 351-372. Web of Science. Accessed on March 15, 2011.

Ingersoll, Earl (2003) "Waiting for the End: Closure in Margaret Atwood's The Blind Assassin." Studies in the Novel 35 (4): 543-58. Academic Search Premier. Accessed on March 30, 2010.

Howells, Coral Ann (ed.) (2006) The Cambridge Companion to Margaret Atwood. Cambridge: Cambridge University Press.

$\mathrm{Ku}$, Chung-Hao (2004) "Eating, Cleaning, and Writing: Female Abjection and Subjectivity in Margaret Atwood's The Blind Assassin." Concentric: Literary and Cultural Studies 30 (1): 93-129. Accessed on April 4, 2010.

Lee, Alison (1997) Angela Carter. New York: Twayne.

McWilliams, Ellen (2009) Margaret Atwood and the Female Bildungsroman. Surrey: Ashgate.

Morris, Pam (1993) Literature and Feminism: An Introduction. Oxford: Blackwell Publishers.

Peach, Linden (2009) Angela Carter. 2nd ed. Houndsmills: Palgrave Macmillan.

Roessner, Jeffrey (2002) "Writing a History of Difference: Jeanette Winterson's Sexing the Cherry and Angela Carter's Wise Children." College Literature 29 (1): 102-22. Expanded Academic ASAP. Accessed on January 29, 2011.

Simon, Julia (2004) Rewriting the Body: Desire, Gender and Power in Selected Novels by Angela Carter. Frankfurt am Main: Peter Lang.

Smith, Sidonie and Julia Watson (eds.) (1998) Women, Autobiography, Theory: A Reader. Madison: University of Wisconsin Press.

Staels, Hilde (2004) “Atwood's Specular Narrative: The Blind Assassin.” English Studies 85 (2): 147-160. Academic Search Premier. Accessed on March 18, 2011.

Stein, Karen F. (2003) “A Left-Handed Story: The Blind Assassin.” In: Wilson, Sharon Rose (ed.) Margaret Atwood's Textual Assassinations: Recent Poetry and Fiction. Columbus: Ohio State University Press, $135-54$.

Stein, Karen F. (2003) “Talking Back to Bluebeard: Atwood's Fictional Storytellers.” In: Wilson, Sharon Rose (ed.) Margaret Atwood's Textual Assassinations: Recent Poetry and Fiction. Columbus: Ohio State University Press, 154-173.

Tolan, Fiona (2007) Margaret Atwood: Feminism and Fiction. Amsterdam: Rodopi.

Tolan, Fiona (2010) “'Was I My Sister's Keeper?': The Blind Assassin and Problematic Feminisms". In: Bouson, J. Brooks (ed.) Margaret Atwood: The Robber Bride, Alias Grace, Oryx and Crake. London and New York: Continuum, 74-88.

Vickroy, Laurie (2013) "Sexual Trauma, Ethics, and the Reader in the Works of Margaret Atwood." In: Bouson, J. Brooks (ed.) Critical Insights: Margaret Atwood. Ipswich: Salem Press, 254-267. Warhol, Robyn R., and Diane Herndl Price (eds.) (1997) Feminisms: An Anthology of Literary Theory and Criticism. New Brunswick: Rutgers University Press.

Waugh, Patricia (1989) Feminine Fictions: Revisiting the Postmodern. London: Routledge.

Wilson, Sharon Rose (ed.) (2003) Margaret Atwood's Textual Assassinations: Recent Poetry and Fiction. Columbus: Ohio State University Press.

Wilson, Sharon Rose (ed.) (2013) Critical Insights: Margaret Atwood. Ipswich: Salem Press. 
Katarína Labudoví teaches British and Canadian Literature at the Department of English Language and Literature, Faculty of Arts and Letters, Catholic University in Ružomberok, Slovakia. She gained her Ph.D in the field of Comparative Literatures at the University of Masaryk, Brno, Czech Republic. Her dissertation deals with Angela Carter's and Margaret Atwood's strategies of writing beyond genre conventions. Katarína Labudová has published several articles focused on Margaret Atwood, Angela Carter, identity, monstrosity and the representations of the body in postmodern literatures.

Address: Katarína Labudová, Ph.D., Department of English Language and Literature, Faculty of Arts and Letters, Catholic University in Ružomberok, Hrabovská cesta 1, 03401 Ružomberok, Slovakia. [email: katarina.labudova@ku.sk] 